\title{
Consensus
}

Volume 21

Issue 1 Women and Men in Theological Education:

Article 17

Exploring the Present, Creating the Future

5-1-1995

\section{The five gospels: the search for the authentic words of Jesus: a new translation and commentary}

Carol J. Schlueter

Follow this and additional works at: http://scholars.wlu.ca/consensus

\section{Recommended Citation}

Schlueter, Carol J. (1995) "The five gospels: the search for the authentic words of Jesus: a new translation and commentary," Consensus: Vol. 21 : Iss. 1 , Article 17.

Available at: http://scholars.wlu.ca/consensus/vol21/iss1/17

This Book Reviews is brought to you for free and open access by Scholars Commons @ Laurier. It has been accepted for inclusion in Consensus by an authorized editor of Scholars Commons @ Laurier. For more information, please contact scholarscommons@wlu.ca. 
later construction. The nature miracles, especially the sea miracles, cannot, I think, bear this interpretation, but given the importance of conquest of the sea, both figuratively and actually, in Imperial propaganda, fit better into Crossan's anti-colonial reading of the exorcisms. And, while granting that much of the passion narratives is scripture-generated rather than historical recollection, many critics would argue for somewhat more historical recollection than Crossan allows.

The great virtues of Crossan's volume are its clarity and coherence of argument. His conclusions are bound to be troubling, but throughout, it is clear that they derive from a carefully articulated method that strenuously resists producing a Jesus congenial with the writer. If Crossan's Jesus is a troubling figure, perhaps it was that Jesus was a troubling figure.

John S. Kloppenborg

University of St. Michael's College,

Toronto School of Theology

\section{The Five Gospels, The Search for the Authentic Words of Jesus}

Translation and Commentary by Robert W. Funk and Roy W. Hoover

New York: MacMillan Publishing Co., 1993

Every critical edition of the Greek New Testament involves hundreds of thousands of individual judgments. The Fellows of the Jesus Seminar have developed their own critical edition of the gospels called the Scholars Version. Now we can read the results from The Jesus Seminar published in The Five Gospels, The Search for the Authentic Words of Jesus, a new translation and commentary by Robert W. Funk and Roy W. Hoover, and the Jesus Seminar, (New York: MacMillan Publishing Co., 1993). In addition to a fresh translation of the Synoptic Gospels and the Gospel of John, it also includes the Gospel of Thomas, a translation from the Coptic Gospel of Thomas found in 1945 in Nag Hammadi and earlier Greek fragments. This addition helps to round out the historical picture of gospel writings.

Called the Scholars Version, the book is organized with Mark leading the others since scholars believe that Mark is the earliest gospel. The work was begun in 1985 with thirty scholars taking up the challenge. Eventually more than two hundred joined the Fellows of the Seminar. They met twice a year to discuss papers and to vote with coloured beads (from red as an unequivocal indicator through pink, gray, and finally black as not probable) to indicate the degree of alleged authenticity of Jesus' words. The fact that some words attributed to Jesus were not likely spoken by him does not diminish their importance. 
The work is significant because if attempts to give integrity to the style and content of each gospel in its own right without imposing modern standards of smooth, polite writing upon the works. There is no attempt to level out the translations of the gospels and pious terms are avoided. In the case of Matthew 23:13, for example, since "Woe" is not part of contemporary conversation, the scholars chose to omit the word and to express the word in contemporary English. The Scholars Version reads, "You scholars and Pharisees, you impostors! Damn you! You slam the door of Heaven's domain in people's faces. You yourselves don't enter, and you block the way of those trying to enter." In a different example, the sentence "He who has ears to hear let him hear!" is rendered "Anyone here with two good ears had better listen!" The Scholars Version is a more contemporary expression and it also preserves the assonance of the Greek text. Here/hear reminds the English ear of the other. "Anyone here with two good ears' has the succession sounds- ere, ear, which suggests the assonance of the Greek text, which may be transliterated as ota akouein akoueto (the succession of akou-, akou- and of ota, -eto, with a shift in vowels)" (p. xiv).

Style is an important consideration in translation. The Scholars Version tries to keep Mark as close to street language as possible, saying that the King James Version distorts Mark's orality by shifting present and imperfect tenses to simple pasts. While the translation represents the original Greek text more accurately in English translation, there was no attempt to edit out the social and cultural features of the text. For example, there are still slaves in the text, uncomplimentary stereotypes, and a male-dominated worldview.

The Seminar intends to make its research more available to churches and synagogues and to ordinary folk than scholars usually do. They believe that TV evangelists, other media, and slick magazines prey on the fears of the uninformed.

Seven pillars of scholarly wisdom are discussed in the introduction. In brief, they include: the recognition of the difference between the Jesus of history and the Christ of faith of the creeds, the recognition of the Jesus of the Synoptic gospels as closer than the Gospel of John to the historical Jesus, the recognition of the gospel of Mark as prior to Matthew and Luke, the hypothesis of the source $\mathrm{Q}$ as the explanation for the material which Matthew and Luke have in common in addition to dependence on Mark, the liberation of the non-eschatological Jesus from Schweitzer's eschatological Jesus, the acknowledgement of the Jesus of the gospels as an imaginative theological construct and therefore the search for his words as a search for the historical Jesus, the recognition of the fundamental difference between oral culture and a print culture, and that the burden of proof for historicity of the gospels rests upon the scholars.

While the Jesus Seminar investigated the narratives in minute detail and published their findings, they readily acknowledge that there are never guarantees of results. One of the most insightful questions they pose is 
whether the Jesus we have found is the Jesus we wanted to find. "The last temptation is to create Jesus in our own image, to marshal the facts to support preconceived convictions" (p. 5). It is this temptation which has led the Jesus Seminar as its final general rule: Beware of finding a Jesus entirely congenial to you. This is a message each of us who preaches and teaches in the church needs to hear. I think that this book is a necessity in the library of every pastor.

Carol J. Schlueter

Waterloo Lutheran Seminary

\section{Israel and the Politics of Land: A Theological Case Study \\ W. Eugene March}

Foreword by Walter Brueggemann

Louisville: Westminster/John Knox Press, 1994

112 pp. $\$ 12.99$ U.S. paper

This timely book reached my desk fresh from the publisher one week before leaving on a Study Tour to Israel and the Occupied Territories. The author takes the reader on a fascinating historical and theological journey beginning with Abraham and Sarah and ending with the dramatic Israeli-Palestinian Liberation Organization peace accord signed in September, 1993.

The author's thesis is that "[L]and is best understood as a divine loan intended for responsible (righteous and just) use. Human communities require land, but they can never claim full ownership and are ever to be judged by how they exercise dominion over the land" (p. xi).

"People and Land: Many Faces, Many Voices" heads the engaging first chapter sketching the profiles of several true-to-life Arabs and Jews who daily wend their way through the Damascus and Jaffa gates.

Chapter 2, "The Realities of History: People, Power, and Palestine", sketches the history of the land from Roman times, ending with the Arafat and Rabin handshake in Washington, D.C. on September 13, 1993. March evoked shivering chills in this reviewer at the memory of September, 1982, when Lebanese Christian militiamen entered two Palestinian refugee camps, Sabra and Shatila, under protective cover of Israeli army units, and mercilessly slaughtered hundreds of people, mostly women and children.

Chapter 3, "God and Earth-keeping: Biblical Perspectives on Land", presents a standard from which to assess earth-keeping, i.e. "[T]he success or failure of every attempt at dominion can be measured against the Bible's call for righteousness, for love, for mercy, for justice" (p. 47).

In Chapter 4, "God's Way and Israel: Theological Reflections on a Particular Land", March meets his greatest challenge. He claims that "[A]ny 